\title{
METODE PENCIPTAAN BIDANG SENI RUPA: Praktek Berbasis Penelitian (practice based risearch), Karya Seni Sebagai Produksi Pengetahuan dan Wacana
}

\author{
Maria Magdalena Nuning. W. ${ }^{*}$ )
}

\begin{abstract}
Every science in fact has its own paradigm, even in a science also can be developed some approaches and methods. The method that used and developed in a creation as much as possible should be in according the object to be studied. In addition the science actually dinamic, constantly evolving, follow the civillization and the advancement of science world.

In academic realm, especially in the field of artistic creation, a person scientifically responsible for the work he/she created. The same thing also applied for usage and development of a model and research method that will be applied to a case of art creations. As far the process could be scientifically explained; systematics in a report in form of thesis or dissertation.

In art cretions, works that created won't have any value when there is no narrative behind the work. This narration can be story behind that creation, note, data, the experiment results, exploration that processed into supporting part of the creation of a masterpiece.
\end{abstract}

Keywords: creation method, IImiah, Practice based research, artist, work of art, audience, science production.

\section{ABSTRAK}

Setiap ilmu pengetahuan pada hakikatnya memiliki paradigmanya masing-masing, bahkan dalam suatu ilmu dapat pula dikembangkan beberapa pendekatan dan metode. Metode yang digunakan dan dikembangkan dalam suatu penciptaan sebisa mungkin harus sesuai dengan objek yang akan diteliti. Selain itu ilmu pengetahuan sebenarnya bersifat dinamis, senantiasa berkembang, mengikuti peradaban dan kemajuan dunia pengetahuan.

Dalam ranah akademis, khususnya dalam bidang penciptaan seni, seseorang memiliki tanggang jawab secara ilmiah atas karya yang diciptakannya. Hal yang sama berlaku bagi penggunaan dan pengembangkan suatu model dan metode penelitian yang akan diterapkan pada sebuah kasus penciptaan sebuah karya seni. Sejauh proses tersebut dapat dijelaskan secara ilmiah, sistematis dalam sebuah laporan berbentuk tesis maupun disertasi.

Dalam penciptaan seni, karya yang diciptakan tidak akan memiliki nilai (value) ketika tidak ada narasi di balik karya tersebut. Narasi ini dapat berupa cerita dibalik karya tersebut, catatan, data-data, hasil eksperimen, eksplorasi yang diolah menjadi bagian pendukung dari terciptanya sebuah karya.

Kata kunci: Metode penciptaan, IImiah, Practice based risearch, seniman, karya seni, audiance, Produksi pengetahuan.

*Maria Magdalena Nuning. W (mariamagdalenanuning@gmail.com), Mahasiswi Magister Kriya-Institut Seni Indonesia, Yogyakarta. 


\section{PENDAHULUAN}

Suatu bidang ilmu tidaklah bisa berdiri sendiri, untuk itu diperlukan ilmuilmu dari disiplin ilmu lain dalam membentuk dan menciptakan ilmu serta kebudayaan baru. (pengetahuan yang diproduksi menjadi budaya). Hal itu disebabkan karna situasi dan kondisi, termasuk disini fakta, data, artefak berada di wilayah yang tidak sama, masih terpenggal-penggal sehingga memerlukan seperangkat alat dan metode untuk merekontruksi semuanya menjadi sebuah teks pengetahuan yang lengkap.

Namun tak bisa dipungkiri bahwa metode atau cara dalam setiap merekonstruksi, mengkaji, dan bahkan menciptakan sesuatu objek atau masalah tidaklah sama, tetapi jelas berbeda. Dalam ranah sebuah penciptaan dan pengkajian pada prinsipnya memiliki cara masingmasing yang memiliki kelebihan dan kekurangan. Namun dalam perkembangan pengetahuan masa kini, tidak menutup kemungkinan masing-masing bidang keilmuan dapat meminjam, mengawinkan dan, mengolaborasikan metode dari ilmu lain, ketika hal tersebut memang diperlukan. Hal ini sering disebut dengan metode multidisiplin atau interdisiplin.

Dalam Konteks ini, penulis akan membahas mengenai metode penciptaan dalam seni rupa. Marx berkata bahwa, betapa seni tidak hanya mimetik dengan maksud utilatarian secara langsung tetapi selalu ada unsur-unsur dalam karya seni yang memiliki tujuan di dalam dirinya sendiri, di mana proses kreatif tidak lain adalah manusia yang beraktivitas dan bermain. Sementara John stuart mill seorang filsuf inggris berpendapat bahwa, budaya, intelektual, atau kesenangan spiritual memiliki arti lebih mendalam dari sekadar kenikmatan fisik.

Terkadang dan seolah-olah para seniman yang berada di wilayah penciptaan seni rupa merasa diintervensi, dinilai dan dikaji melalui ilmu-ilmu sosial bukan ilmu khusus di bidang seni. Terlepas dari itu semua jika kita setuju dengan pendapat Giddens, yang menyatakan bahwa para ilmuwan bukanlah orang pertama-tama yang mengadili seni rupa dengan kategori ilmu-ilmu sosialnya, melainkan masuknya para ilmuwan tersebut dalam dunia seni rupa khusunya dan estetika pada umumnya, sebenarnya bertujuan untuk belajar dan berkomunikasi dengan para seniman maupun 'dunia' yang diciptakan lewat karya-karya mereka.

Keberadaan karya seni tidak semata-mata tanpa tujuan. Seseorang mencipta karya seni pasti memiliki maksud dan tujuan. Maksud dan tujuan itu berupa konsep atau pengertian tentang keindahan yang dapat ditafsirkan. Sebagaimana kenyataan dalam perspektif sosial, hal yang disebut indah atau apakah keindahan itu adalah hasil penafsiran para seniman, kolektor, kritikus seni, penguasa, pengusaha, atau sejarawan, sehingga hasil penafsiran yang berupa pengetahuan akan keindahan merupakan hasil dari bentukan kekuasaan dalam ranah dan konteks tertentu. Focaulth mengatakan bahwa segala sesuatu bisa dibentuk lewat pengetahuan dan kekuasaan, termasuk nilai estetika.

Hauser menyatakan 'seni memiliki realitasnya sendiri' bahwa sejarah memperlihatkan, seni itu bersendikan pada 'realitas' (kenyataan), berarti seni itu 
dibangun oleh manusia atas dasar persepsi (pengamatan manusia) dan kebutuhan, dimana unsur fisik dari objek seni itu lebih penting dari pada yang lainya, sehingga selain karya seni itu penting untuk diciptakan juga sangat perlu dideskripsikan.

Untuk menciptakan dan mendiskripsikan karya seni, bagi seseorang yang berada di wilayah akademik, ia harus mampu menganalisis dan menjelaskan bagaimana karya tersebut diciptakan dan hal apa saja yang terkandung dalam karya tersebut serta bagaimana ia mampu merangkai proses itu dalam bahasa ilmiah, yang pada akhirnya dapat menjadi sebuah pengetahuan yang dapat dipertanggungjawabkan.

\section{PEMBAHASAN}

a. IImiah

Dikatakan ilmiah sejauh tulisan tersebut berkaitan dengan pengetahuan (dimulai abad XIV), pengembangan ilmu, kemajuan peradaban. 'the scientific is a written and published report describing original research results.'

Ilmiah/il.mi.ah menurut kamus

Besar Bahasa Indonesia adalah bersifat ilmu, secara ilmu pengetahuan, memenuhi syarat (Kaidah) Ilmu pengetahuan. Dalam bahasa populer bersifat ilmu, tetapi menggunakan bahasa umum sehingga mudah dipahami oleh masyarakat awam (tentang artikel, gaya penulisan karya ilmiah). Beberapa bentuk karya ilmiah dalam bidang seni adalah penelitian, penciptaan, dan perancangan, dan terdapat penjelasan didalamnya tentang bagaimana proses penciptaan karya tersebut.
Menurut Pemahaman penulis Metode penciptaan dalam Seni rupa bisa di katakan ilmiah, sejauh ia dapat dijelaskan secara logis. Penjelasan secara logis ini dapat ditemukan pada Proses penciptaan, Selain itu penciptaan dalam seni rupa memiliki metode sendiri dikarenakan selain dituntut untuk menjelaskan secara pemikiran atas konsep /ide yang didukung teori-teori dan pendekatannya, juga harus menciptakan karya yang berwujud (actual), di mana hal itu tentunya menggunakan metode yang khusus. Singkatnya, Dalam mengangkat Persoalan atau fenomena, tidak hanya (Know-why) mengetahuimengapa, (to seek meaning) mencari makna/memaknai saja tetapi juga (KnowHow) Mengetahui-bagaimana membuatnya dan juga (to seek form) menghasilkan bentuknya.

Dalam penelitian akademis khususnya bidang seni murni, kriya dan desain, istilah 'penelitian berbasis praktik' (practice-based research) atau (practice-led research) penelitian yang diawali dengan praktik telah muncul sejak tahun 1980-an dan menonjolkan sentral praktik dalam mengumpulkan keterangan melalui kerja praktik mereka sendiri (gray dan Dauglas, 1996). Di Indonesia, bidang penelitian ini termasuk baru, padahal dalam praktiknya kita secara otomatis telah melakukan proses tersebut, hanya saja kita belum terbiasa dengan budaya research, budaya mencatat dan mengumpulkan data-data yang dianggap penting dalam proses penciptaan. 
b. Praktek Berbasis Penelitian (Practicebased Research)

Malins, Ure dan Gray (1996)

mendefinisikan konsep practice-led research sebagai penelitian yang dimulai dari kerja praktik dan melakukan praktik. Mereka menyebutkan hal ini dalam laporan mereka, The Gap: Addressing Practice-Based Research Training Requirements for Designers yang memaparkan bahwa: Penelitian berbasis praktik merupakan penelitian yang paling tepat untuk para perancang karena pengetahuan baru yang didapat dari penelitian dapat diterapkan secara langsung pada bidang yang bersangkutan dan peneliti melakukan yang terbaik menggunakan kemampuan mereka dan pengetahuan yang telah dimiliki pada subjek tersebut (Malins, Ure dan Gray, 1996: 1)

Gray juga menyebutkan beberapa metode spesifik yang digunakan di penelitian berbasis praktik dalam hubunganya dengan pengumpulan informasi misalnya; membuat karya seni, observasi dan penggambaran (dalam segala bentuk), buku sketsa atau catatan, notasi, simbol tertentu, model, eksperimen dengan material-material, pemetaan konsep atau diagram, penggunaan metafora dan analogi, glosarium, arsip visual dan tekstual. Metode-metode tersebut dapat juga diintegrasikan dengan metode-metode ilmu sosial, biasanya diadaptasi dengan berbagai cara, contohnya; 1) studi kasus, 2) Observasi partisipan, 3) Gagasan-gagasan pribadi, 4) Wawancara, kuesioner, 5) Analisis multidimensi, 6) Teknik evaluatif seperti perbedaan semantik, penyortiran beberapa kali.

Dari paragraf di atas maka dapat dilihat tiga komponen penting keberadaan Seniman, Karya seni (art works), dan audiance, dalam siklus yang saling terkait, dan saling mempengaruhi dalam produksi pengetahuan untuk memunculkan, menggali, dan menciptakan nilai baru dari karya seni, dalam hubunganya memproduksi dan menemukan makna yang dapat dilakukan lewat apresiasi.

\section{c. Seniman}

The artist is the origin of the work. The work is the origin of the artist. "Sang seniman adalah muasal karyanya. Karyanya adalah muasal sang seniman." seolah-olah ia hendak mengatakan: Seniman dan karyanya ibarat sekeping mata uang, kedua sisinya tak terpisahkan. Apakah Heidegger hendak menegaskan bahwa ekspresi seniman, bagaimana pun atau apa pun, adalah karya seni dan begitu pula sebaliknya.

Joseph beuys mengatakan setiap orang adalah seniman dan kemudian mencairkan praktek seni dan praktek sehari-hari, sehingga seringkali menjadikan aktifitas seni sukar di jelaskan sebagai sebuah karya seni, la terus menganjurkan sebuah konsep berkesenian yang universal, yang memiliki dimensi luas antar disiplin keilmuan. Menurutnya:

"Setiap orang adalah seniman, saya maksudkan bahwa siapa pun bisa memutuskan kepuasan hidupnya dalam bidang khusus, apakah dalam lukisan, musik, mesin-mesin, mengobati orang sakit, ekonomi, atau apa pun itu!" seru Beuys. Hal tersebut 
karena menurut Beuys lembaga budaya menghadapi dilema dalam mengatasi kenyataan bahwa kebudayaan merupakan sebuah lapangan yang terkucil, dan kesenian lebih terkucil lagi. Yakni sebuah tempat yang sangat terasing dari sebuah lapangan kebudayaan yang dikepung oleh kompleksitas budaya dan pendidikan, juga oleh media yang justru merupakan bagian dari kebudayaan tersebut.

Akan tetapi, kita patut memeriksa perihal "Seniman" dan "Karya Seni". Siapakah dan bilamana seseorang disebut sebagai "Seniman" dan bagaimana sesuatu (benda) karya seni tak lain adalah "benda" lengkap dengan sifat kebendaannya, dianggap sebagai "Karya Seni". Karna dibutuhkan proses dan konsistensi serta metode (cara) untuk menemuh status (profesi) " seniman" tidak hanya berdasarkan kesenangan atau hobi saja, meskipun beuys menyatakan "siapa pun bisa memutuskan kepuasan hidupnya dalam bidang khusus" tetapi apakah hal itu bisa dipertanggungjawabkan.

Dari beberapa statment diatas, memunculkan pertanyaan bagi penulis, apakah seniman adalah sebuah profesi, suatu aktivitas (berkarya) yang bisa dilakukan siapapun, atau siapapun yang dapat menghasilkan karya seni seketika disebut seniman, dan memunculkan kembali pertanyaan bagaimana dengan mereka yang melampaui jalan untuk mencapai statusnya lewat sekolah seni yang memiliki paradigma yang tidak hanya dibangun dalam sehari, mereka memiliki proses dan sejarah yang tidak singkat. Apabila "seniman" bisa disandang oleh siapapun, apa fungsi dari sekolah seni? Sebagai tempat produksi pengetahuan, disisi lain seniman hidup dalam situasi yang krusial, karena seniman dituntut untuk menciptakan sesuatu yang baru dan apakah hal itu bisa dianggap sama, disetarakan dengan 'seniman' yang membuat karyanya dengan alasan" karena saya senang" tanpa tau keberlangsungan seni yang dia ciptakan dan lakukan.

\section{d. Seniman Akademis dan Otodidak}

Disini penulis membatasi perbedaan keduanya sebagai seniman akademis dan seniman otodidak. Tentunya keduanya memiliki proses dan penyikapan yang berbeda, terhadap karyanya, tidak hanya persoalan efek ekonomisnya, meskipun karya seniman otodidak tidak kalah menarik dilihat dari segi visual. Karya seni tidak hanya persoalan bentuk fisik saja, namun nilai (value) yang terkandung di balik karya lah yang membuatnya jauh lebih bernilai sehingga karya seni tidak hanya dilihat sebagai sebuah 'benda'.

Sudah cukup lama kata "seniman" dipakai di sembarang waktu, di sembarang tempat, dan di sembarang keprofesian. Seakan-akan seniman adalah kata generik bersifat umum dan oleh karena itu boleh semena-mena dimanfaatkan oleh siapa saja. Padahal, "seniman" adalah sebuah istilah "spesifik" yang sangat terikat dengan "ukuran-ukuran suatu konteks, norma, ruang dan waktu". (Aminudin, 2012: kompas)

Lalu apa dan siapakah "seniman"
itu?. Apakah batas-batas yang bisa
diberlakukan terhadapnya. Sudjoyono
menyatakan, Istilah "seniman" tidak turun
tiba-tiba dari langit. Orang yang pertama


kali memopulerkan istilah "seniman" adalah sang Bapak seni lukis modern Indonesia: S Sudjojono (1913-1986). Istilah ini sudah mengemuka pada akhir 1930-an di dalam tulisan-tulisan $S$ Sudjojono tentang seni lukis Indonesia. S Sudjojono mengakui bahwa istilah "seniman" ini pertama kali diusulkan oleh Ki Mangun Sarkoro mantan Menteri Pendidikan dan Kebudayaan RI (1949-1950). Dengan kata dasar 'seni', maka "seniman" adalah seseorang yang mengerjakan, menciptakan karya yang hasilnya nanti disebut seni. Definisi ini ternyata tidak cukup memadai.

Dalam bukunya Seni Loekis, Kesenian dan Seniman (1946), S Sudjojono menyarankan sejumlah syarat tambahan agar seseorang pantas disebut "seniman" atau "tidak". Antara lain ia mengatakan bahwa kerja seorang "seniman" tidak semata-mata berurusan dengan soal kecakapan dalam soal teknis saja (misalnya menggambar atau melukis). Lebih dari itu, untuk menjadi "seniman" yang baik dan benar, kata S Sudjojono, seseorang itu harus memiliki watak dan jiwa yang besar (sebab seni adalah jiwa tampak, katanya).

Penting diketahui bahwa
"seniman" dimanfaatkan oleh S Sudjojono untuk menggantikan istilah 'artist', 'kunstler', 'kunstenaar'. Pada akhir 1940an, sang proklamator Seni lukis Indonesia inilah yang kemudian menciptakan istilah 'pelukis' sebagai pengganti kata 'schilder'. la juga orang yang berhasil menasionalkan istilah 'atelier', 'workshop' atau 'studio' dengan kata 'sanggar' yang masih kita gunakan sampai sekarang.

S Sudjojono mengklasifikasi perbedaan 'pelukis' dengan 'seniman' secara definitif. Menurut dia, seorang 'pelukis' tidak bisa mematut diri sebagai 'seniman'. Dengan begitu, posisi 'seniman' ditempatkan $\mathrm{S}$ Sudjojono lebih tinggi secara hierarki ketimbang 'pelukis' (hierarki ini juga berlaku di Barat, yaitu batasan antara (painter) dengan (artist). Seniman besar seperti Affandi bahkan selalu merendah: "Saya ini hanya tukang gambar". Seperti halnya S Sudjojono, Affandi juga memandang tinggi status seniman. Menjadi seniman adalah proses, dan peran publik tak kalah penting dalam proses tersebut.

S Sudjojono adalah orang yang mendefinisikan "seniman", dengan syarat kemudian diformulasikan lalu dipopulerkan. Sekalipun sudah cukup lama, dasar-dasar pengertian yang pernah dibangun oleh $S$ Sudjojono ini kenyataannya masih relevan dengan situasi zaman kita sekarang. Dengan definisi itu, kita, misalnya, bisa menilai mana "seni yang medioker" dan "mana yang bukan"; mana yang pseudo art dan mana yang sungguhan.

Di sinilah pangkal perdebatannya: ada perbedaan antara nama dan "Nama". la terkait dengan "the economy of recognation", begitu tulis Goenawan Mohamad (risalah Sebuah Torpis, sederet "nama", 2005), di dalamnya terkandung pengertian "fetisisme komoditas" Marx, yakni mistifikasi sesuatu barang atau nama dengan derajat nilai ekonomis lebih ketimbang nilai guna atau reputasinya. Goenawan Mohamad, seorang jurnalis cum sastrawan Indonesia menuliskan; "Nama" itu beroleh nilai tukarnya sendiri, yang kemudian disebut 'harga', sebuah penilaian yang terlepas dari kegairahan atau pun 
jerih-payah sang seniman ketika ia melahirkan sebuah karya.

Dari pernyataan Gunawan Muhamad dan sudjoyono di atas, maka dapat disimpulkan batasan dan beda seniman dengan "seniman". Bagaimana Gunawan muhamad melihat 'status' dari sebuah "nama" (sebagai bentuk efek eksistensi dari proses, yang disebut sudjoyono; bahwa menjadi seniman itu proses), sebagai bentuk pilihan yang dipilih dan ditempuh secara total, dan kemudian proses tersebut memiliki nilai yang diakui pihak lain, berdasarkan usaha yang dia tempuh, sederhananya, nilai tukar ini bisa dikatakan respon terhadap usaha yang ia tempuh dalam mencapai profesi kesenimananya, dan ketika seorang yang sedang menempuh status kesenimananya lewat jalur akademis maka ia memiliki tanggungjawab serta kesadaran terhadap karya yang diciptakan sebagai sebuah pengetahuan, lewat laporan tertulis (skripsi, tesis, dan disertasi) yang dapat dijelaskan secara sistematik. Maka sebagai seorang seniman, ia memiliki latar belakang dan landasan yang kuat tentang apa, mengapa bagaimana, seni dan karyanya diciptakan, sehingga tulisan dan hasil pemikiranya memberikan efek dan pengaruh bagi keberlangsungan pengetahuan selanjutnya, sehingga seni tersebut tidak hanya berhenti di karya saja.

Misalnya, putu sutawijaya, sebagai seorang pelukis yang sudah dikenal di kancah seni rupa dunia, apalagi di balai lelang seperti christy's dan sotebhy's otomatis ia memiliki nilai tukar (dari "nama" yang telah dikenal dunia lewat karyanya) atas usaha yang ditempuhnya. Usaha atau proses yang tentunya tidak diperoleh secara singkat, la menempuh lewat sekolah seni pada saat itu bernama Akademi Seni Rupa Indonesia (ASRI), guna untuk mempelajari metode-metode penciptaan seni, struktur, elemen-elemen seni, mempelajari estetika sebagai dasar filsafat keindahan yang digunakan untuk menciptakan karyanya.

Berbeda lagi dengan Tisna Sanjaya ia seorang seniman yang memperoleh status senimannya melalui jalur akademis. Tisna sanjaya merupakan seniman yang cerdas. la memiliki kesadaran tentang keberlanjutan seni yang dia hadirkan, kemampuan untuk mengkaitkan persoalan dan meleburkan seni yang didapat melalui lembaga pendidikan dikolaborasikan dengan praktik-praktik di lapangan, yang dikaitkan dengan masyarakat melalui research (pustaka dan lapangan), disinilah eksperimen yang dilakukan Tisna sanjaya dengan menggunakan metode yang dipraktekkan dalam menciptakan karya seni mereka.

Pengetahuan yang didapatkan di jalur akademis menjadi tidak kaku ketika dipraktekkan ke dalam masyarakat, tentunya karena seniman tersebut memiliki kemampuan dalam mengolah ide, gagasan dan konsepnya lewat berfifikir kreatif.

Orang yang menyandang profesi seniman, terlepas dia selesai atau tidak melewati proses akademis atau sekolah seni, setidaknya ia pernah berada pada wilayah akademis sehingga memiliki pemahaman dalam proses penciptaan karyanya lewat cara (metode) dan tahapan-tahapan dan didukung dengan kognitif yang dia miliki sebagai modal dalam menghasilkan karya-karyanya. 
Pemahaman ini berupa pengetahuan dalam proses penciptaan sebuah karya seni.

Dengan modal pemahaman yang dia miliki maka seorang seniman akan mampu menciptakan karya yang tidak hanya bernilai fisik saja, tetapi juga dapat berfikir dan menjelaskan secara terstruktur, mulai dar ide/gagasa/konsep, hingga tahapan proses perwujudan yang dapat dijelaskan dan mampu menganalisis proses tersebut, dan secara sadar praktik seni tersebut berpotensi sebagai sebuah pembelajaran atau pengetahuan (transfer knowladge).

\section{e. Seni dan Karya Seni}

Sebelum berbicara tentang apakah karya seni, ada baiknya kita mencoba memahami apakah seni itu?. Secara umum istilah seni biasanya selalu dihubungkan dengan pengertian indah. Seni adalah nyata dan bagian dari kehidupan, dimana seni adalah sesuatu yang bergerak secara dinamis, serta memiliki kemungkinan pengertian yang sangat luas. Ketika dikaitkan dengan berbagai wujud eksistensialnya yang mengikat bentuk ruang, waktu, dan tanggapan-tanggapan manusiawi, kebudayaan, dan lingkungan.

Ini karena seni, sebagai bagian dari kebudayaan manusia, berjalan dan berkelanjutan dengan seluruh segi kehidupan manusia yang sangat luas, rumit, dan kompleks. Seni sangat berbeda dengan ilmu pengetahuan yang bekerja secara pasti untuk mendapatkan hasil yang obyektif dan dapat diukur. Karena seni tidak hanya berupa hasil akal fikiran, tetapi menyentuh dan melibatkan perasaan (hati) yang subyektif.
Seni itu sama sederhananya dengan seni yang sulit seni itu seperti keindahan, yang berada pada mata yang melihatnya, sehingga keindahan pun relatif. Bagi orang lain, seni merupakan suatu objek atau gambaran yang didefinisikan oleh pembuatnya. Seni juga dapat berupa objek atau gambaran yang diidentifikasi secara tidak eksplisit seperti itu, tetapi yang memantik pengamat sebagai sesuatu yang ekspresif atau menyenangkan secara estetis.(the methodologi of art, :2)

Tentang seni, Herberth Marcuse dalam Art as Form of reality membuat pembatas sebagai berikut:

I shall used term'form' as that which art as art, that is to say, as essentially (ontologically) different not only from (everyday) reality but also from such the other manifestation of intellectual culture as science and philosophy. (Marcuse: 123: 1971).

Sebelum adanya sejarah seni, dan metodologi-metodologi yang terdapat dalam buku, ada filsafat. Para filsuf telah menguraikan hakikat seni dan respons estetis. Bagi Plato, seni visual merupakan mimesis, dalam bahasa Yunani "peniruan" dan tecne, atau "keterampilan". Keindahan merupakan sebuah hal ideal dan intisari yang mengekspresikan kebenaran hal-hal yang ada. Tetapi menurut Plato, keindahan dan kebenaran berada pada tingkat yang lebih tinggi dari pada seni. Faktanya, ia hanya memiliki sedikit minat terhadap karya seni karena hal tersebut bukan merupakan peniruan yang berguna dari gagasan-gagasan inti maupun gagasangagasan itu sendiri. 
Berbeda dengan Plato dan tradisi Platonik mengenai intisari ideal yang para seniman usahakan untuk menirunya, Aristoteles memberi lebih banyak kemungkinan. Meskipun ia mengikuti Plato terkait konsep dasar seni sebagai gabungan mimesis dan techne, ia tidak membatasinya pada salinan yang tepat, atau "inti". Menurut Aristoteles, guna mengetahui sesuatu, seseorang harus mengetahui persoalannya, pembuatnya, dan tujuannya, sebaik ia mengetahui bentuknya. la merasa bahwa seni dapat menyempurnakan alam dengan berbagai cara, seperti pengidealisasian dan pengkarikaturan. Hal-hal tersebut mencapai "intisari" dari hal yang berbeda, dan memberikan karya seni beberapa dasar bagi persepsi sang seniman.

\begin{tabular}{|c|c|c|}
\hline & Plato & Aristoteles \\
\hline SENI & $\begin{array}{l}\text { - Menganggap } \\
\text { gambaran- } \\
\text { gambaranmereka(senim } \\
\text { an)menyimpang dari } \\
\text { kebenaran (dan oleh } \\
\text { karena itu dari Yang } \\
\text { Baik dan yang indah } \\
\text { kalos k'agathos). } \\
\text { - keberatan pada seni } \\
\text { dan pada musik dan } \\
\text { puisi karena dapat } \\
\text { menyulut hasrat yang } \\
\text { merusak (destructive } \\
\text { passions) }\end{array}$ & $\begin{array}{l}\text { - Percaya pada } \\
\text { kekuatan seni } \\
\text { untuk } \\
\text { memperbaiki } \\
\text { kekurangan alam. } \\
\text { Kedudukan } \\
\text { filosofis ini } \\
\text { menyebut asal } \\
\text { muasal seni } \\
\text { drama seperti } \\
\text { hakikatnya. }\end{array}$ \\
\hline $\begin{array}{l}\text { POSISI } \\
\text { DAN } \\
\text { FUNGSI } \\
\text { (proses) }\end{array}$ & $\begin{array}{l}\text { seni berasal dari suatu } \\
\text { hal yang ideal, tapi } \\
\text { jaraknya dari hal ideal } \\
\text { itu membuatnya tidak } \\
\text { berguna dan } \\
\text { kemungkinan berbahaya }\end{array}$ & $\begin{array}{l}\text { seni dapat } \\
\text { menjadi sebuah } \\
\text { jalan menuju } \\
\text { pengetahuan. la } \\
\text { percaya bahwa } \\
\text { kita senang pada } \\
\text { sebuah tiruan } \\
\text { yang baik, karena } \\
\text { kita dapat belajar } \\
\text { darinya, dan } \\
\text { bahwa hal }\end{array}$ \\
\hline
\end{tabular}

\begin{tabular}{|l|l|l|}
\hline & & $\begin{array}{l}\text { tersebut membuat } \\
\text { kita menyenangi } \\
\text { pembelajaran itu } \\
\text { sendiri. }\end{array}$ \\
\hline GAGAS & $\begin{array}{l}\text { gagasan-gagasan dan } \\
\text { otentik—dan bukan } \\
\text { AN } \\
\text { keninya mengandung } \\
\text { kebenaran dan } \\
\text { keindahan, }\end{array}$ & $\begin{array}{l}\text { kebenaran dan } \\
\text { keindahan } \\
\text { terkandung dalam } \\
\text { bentuk dan } \\
\text { susunan seni. }\end{array}$ \\
\hline
\end{tabular}

Gambar 1. Tabel perpedaan Plato dan

Aristoteles tentang seni

Berbicara karya seni rupa pastilah merujuk pada sesuatu yang dapat dideskripsikan, dimensi fisik, untuk itu kita perlu mengenal tiga hal utama dalam dimensi fisik karya seni yang bersangkutan, yaitu subject matter, medium dan form.

Subject matter (Materi subjek), dalam karya seni adalah figur-figur, objekobjek, tempat-tempat dan pariwisatapariwisata yang dilukiskan dalam karya seni. Sebagai ilustrasi, kita bisa lihat karya milik Tisna sanjaya berjudul "Instalasi tumbuh" (1996), Agar bisa memahami permasalahan dia melakukan penelitian dengan mengamati permasalahan lebih dahulu dalam atau wawancara dengan masyarakat berkaitan dengan permasalahan yang akan diangkat dalam penciptaanya.

Medium, Kadangkala istilah medium dipakai untuk mengatakan sesuatu kategori fisik karya seni secara umum seperti medium seni lukis, atau medium seni patung, performance art dan video. Istilah ini juga dipakai mengidentifikasikan materi-materi spesifik yang dipakai oleh seorang seniman, seperti lukisan acrylic, serat kaca, kayu, tembaga, dan sebagainya. Medium yang digunakan Tisna dalam karyanya adalah performance art, baginya media ini bisa berkomunikasi 
langsung dan berinteraksi dengan masyarakat. Di situ ia membagikan 99 pohon mahoni, dan 99 pohon mlinjo kepada masyarakat di Bandung, solo, dan Surabaya.

Form, semua karya seni memiliki forma atau bentuk, bentuk itu bisa realistik atau abstrak, representasional atau non representasional dibuat secara cermat dengan persiapan matang atau dibuat secara spontan ekspresif. Biasanya kritikus seni selain mendiskusikan bentuk suatu karya seni, seorang kritikus juga memberikan informasi yang menerangkan bagaimana seniman menyampaikan materi (subject matter) karyanya melalui medium yang dipilih, dan yang dibicarakan adalah komposisinya, mendiskusikan aransementnya, dan konstruksi visualnya. Elemen-elemen formal karya seni meliputi titik, garis, shape, cahaya, teksture, massa, ruang, dan isi. Bagaimana elemen-elemen ini diorganisir, sering dikatakan sebagai 'prinsip-prinsip desain' atau prinsip-prinsip mengorganisisr elemen-elemen visual. Prinsip-prinsip itu meliputi skala, proporsi, unity/kesatuan/kepaduan dalam keragaman, repetisis, ritme, keseimbangan, kekuatan arah, kontras, penekanan, dominasi dan subordinasi (Marianto, 2002; 6)

Dari uraian diatas dijelaskan bahwa karya seni yang memiliki dimensi fisik menjadi bagian yang vital untuk dideskripsikan, jelas bahwa deskripsi bukan sekedar awalan untuk melangkah ke kritik. Tulisan yang detail dari seorang kritikus terhadap karya seni yang kemudian akan memberikan pengetahuan dan apresiasi kepada pembaca, sehingga keberadaan karya seni menjadi sarat interpretasi dan penilaian lewat bahasa, untuk memfasilitasi pemahaman dan apresiasi terhadap karya seni.

\section{f. Bagaimana Karya Seni Tercipta Dari Tangan Seniman}

Secara umum, pada awal proses penciptaan karya seni, seniman bersentuhan dengan rangsangan atau impuls yang sengaja ditentukan maupun tak sengaja disentuhnya (mempersepsi). Dalam proses persentuhan tersebut terjadi suatu gambaran atau suatu bentuk pemahaman dalam pikiranya. Gambaran ataupun bentuk pemahaman itu yang biasanya disebut dengan 'ide' atau 'konsep' dan selanjutnya cakupan ide yang dipakai disini juga meliputi sensasi dan semua jenis khayalan mental. Jadi pengertian berfikir pun mencakup segala aktivitas manusia yang dapat melibatkan setiap mekanisme penghayatan sehingga menghasilkan

ide/gagasan/konsep/pemikiran dalam pengertianya yang lebih luas. Ide /gagasan /konsep/pemikiran merupakan segala gambaran dan cita-rasa yang dapat terbentuk dalam diri seniman), yaitu suatu kualitas abstraksi yang selanjutnya di realisasikan dalam laku/ cara/tahapan (proses) karya-karya seni yang dibuat.

Abstraksi; Proses yang ditempuh pikiran untuk sampai pada konsep yang bersifat universal. Proses ini berangkat dari pengetahuan mengenai objek individual yang bersifat melampaui ruang dan waktu. Berasal dari bahasa latin abstractio (dari abstrahere, berarti menarik diri). 
Ide tersebut merupakan hasil pertemuan anatara kesatuan subjek-objek dunia luar yang terolah atau dalam bentuk rangsangan. Kesatuan subjek berarti akan menyangkut kedudukan manusia (seniman) dengan segala hal yang sangat kompleks dan rumit, mencakup semua mekanisme yang berlangsung didalamnya atau mencakup suatu kesatuan daya menghayat (merefleksikan) yang aktif mempunyai arah, tujuan, dan kehendak, sedangkan objek dunia luar adalah semua gejala atau rangsangan yang didapat.

Prose Penciptaan dan metode berkarya menjadi hal penting dalam wilayah penciptaan. Konsep karya seni berupa cerapan, bayangan dalam pikiran yang mendesak untuk di realisasikan. Sehingga dalam penciptaan karya seni rupa dibutuhkan proses penciptaan untuk mewujudkan konsep tersebut. Hal-hal paling mendasar dalam sebuah proses penciptaan yang dapat diwujudkan dalam proposal perancangan terdiri dari beberapa komponen. Komponen tersebut antara lain; 1)Latar belakang, 2) Permasalahan/ide penciptaan, 3) Eksplorasi karya dan pencarian pustaka terkait, 4) Metode eksplorasi, 5) Proses penciptaan, masing-masing komponen tersebut dapat diperluas disesuaikan dengan kebutuhan.

Eksplorasi dalam seni rupa seringkali digunakan dengan tujuan mematangkan, permasalahan dan ide penciptaan serta pengalaman empiris yang intens lewat komunikasi dengan data-data visual (artefak) pada karya-karya selektif dan pustaka terkait. Mematangkan berarti, mengumpulkan modal kreatif, inovatif melalui proses berfikir kreatif sehingga seorang pencipta atau seniman memiliki sesuatu yang siap dieksekusi. Metode eksplorasi ini dapat dilakukan di studio, ataupun lapangan yang dipilih lapangan bisa saja pasar, candi, desa, dsb. Dalam hal ini sumber kreatif itu adalah pengalaman empirik, lapangan dipilih dengan asumsi bahwa sumber kreatif tidak bisa didapat dari karya-karya orang lain, melainkan pengalaman empirik di lapangan.

Proses ini dapat menggunakan dasar pemikiran penelitian tindakan (Action Research) sebagai metode dan alat penelitian yang potensial. Pokok dari kerja praktik yang dihasilkan melalui proses eksperimental telah memberikan bukti, yang sejalan dengan tujuan utama penyelidikan untuk untuk mengetahui segala kemungkinan misalnya, yang akan dibuat adalah karya ceramic berbentuk teko, maka yang dilakukan adalah (eksperimen material yakni tanah yang akan digunakan, struktur, konstruksi, dan bentuk), kemudian membuat tes piece dari material tanah (porcelaine, stoneware, earthenware), guna mengetahui tingkat kematangan tanah ketika akan dibakar di tungku pada suhu tertentu. Hasil dari penelitian kemudian didokumentasikan untuk referensi dalam mengembangkan penerapan atau penggunaan material tanah pada karya ceramic.

Mcniff, Lornax, dan Whitehead (1996) telah mengembangkan pandanganpandangan dari penelitian tindakan yang dirasa tepat pada pandangan para peneliti dalam melakukan penelitian tindakan:

"Penelitian tindakan merupakan jalan untuk mendefinisikan dan mengimpleentasikan perkembangan profesional yang 
relevan. Penelitian tindakan dapat memanfaatkan bentuk-bentuk kerja sama dan partisipasi, yang tidak begitu efektif, yang menjadi bagian retorika profesional... dimulai dengan seseorang berkomitmen untuk fokus pada pekerjaanya. Dari hal tersebut di dapat momentum melalui keterlibatan satu sama lain sebagai kolaborator dan menjalar ke yang lainya ketika individu merefleksikan sifat dari partisipasinya dan prinsip kepemilikan bersama pun tercipta. Hal ini dapat membuahkan pembentukan komunitas yang kritis; para profesional dalam pengertian yang baik. (Lomax, 1990:10)

Dick menjelaskan, metodologi penelitian tindakan mempunyai tujuan rangkap dari tindakan dan penelitian. Dick mendefinisikan tindakan sebagai perubahan di beberapa komunitas atau organisasi atau program. Sedangkan penelitian berhubungan dengan memahami bagian dari peneliti atau klien atau keduanya (di komunitas yang lebih besar). Dick juga menjelaskan penggunaan penelitian tindakan dari pengalamanpengalamannya, yang memberikan penekanan penting pada 'tindakan' dengan penelitian sebagaisuatu keuntungan lain dalam bentuk meningkatnya pemahaman pada bagian yang terlibat secara langsung. Hasil dari penerapan metodologi ini merupakan hasil perubahan dari pembelajaran bagi mereka yang ikut ambil bagian. Kedua pendekatan memerlukan tindakan untuk memaparkan pemahaman, dan pemahaman untuk menopang tindakan. (Dick, 1993: 8)
Dalam studi Ph.Dnya Warbuton berpendapat bahwa metodologi penelitian tindakan juga bisa ditemukan pada program practice-led research yang memanfaatkan material-material penelitian, aktivitas, dan hasil dari praktik kehidupan sehari-hari. la menyarankan bahwa aktivitas dan hasil praktik dapat dianggap sebagai aktivitas penelitian jika memiliki jawaban postif dari lima pertanyaan ini; 1) Apakah aktivitas praktik merupakan penyelidikan yang sasaranya adalah pengetahuan?, 2) Apakah dilakukan secara sistematik?, 3) Apakah data tersebut eksplisit?, 4) Apakah catatan dari pelaksanaan aktivitas 'transparan'?,5) Apakah data dan hasilnya divalidasi dengan cara yang tepat?.

Pertanyaan-pertanyaan yang diajukan tersebut mendefinisikan kualitas dari aktivitas praktik, yang juga menjelaskan aktivitas penelitian sebagai penyelidikan sistematis yang sasaranya adalah suatu pengetahuan yang dapat disebarluaskan. Warbuton juga mengutip presentasi Frayling, mengacu pada 3 klasifikasi dalam penelitian seni dan desain:

1. Penelitian tentang praktik

2. Penelitian untuk tujuan praktik, dan

3. Penelitian melalui medium praktik.

Klasifikasi di atas menunjuk pentingnya 'praktik' dalam penelitian, yang kebetulan sama dengan pendekatan teoritis dari cara penyelidikan penelitian tindakan. Penelitian berdasarkan praktik dan proses berhubungan dengan penelitian melalui mediumnya. Agar para praktisi dapat menyampaikan proses yang tersirat, metodologi penelitian tindakan merupakan metode yang tepat digunakan dalam penciptaan seni rupa. 


\section{g. Seni Sebagai Produksi Pengetahuan}

Hubungan kita dengan realitas diatur melalui berbagai wacana, yang menentukkan bagaimana seharusnya dan sebaiknya bertindak, membentuk kepercayaan-kepercayaan, konsep, dan ide-ide yang kita anut. Realitas disini dipahami sebagai seperangkat konstruk yang dibentuk melalui wacana, karena wacana memiliki keterkaitan dengan kenyataan. Realitas menurut foucault, tidak bisa didefinisikan jika kita tidak mempunyai akses dengan pembentukan struktur diskursif tersebut. Realitas dalam konteks ini adalah seni, seni yang berkembang dinamis yang selalu dipahami sesuai konteksnya.

Dalam tujuanya memproduksi pengetahuan (knowladge) dan wacana (discourse) dalam seni, dapat dilakukan lewat apresiasi seni. Apresiasi dapat dilakukan dengan banyak cara, serta dapat dilakukan oleh orang-orang yang berkepentingan di dalamnya (audiance), dikarenakan apresiasi merupakan bagian dari cara memproduksi makna.

Discourse adalah cara
menghasilkan pengetahuan,
beserta praktik sosial yang
menyertainya, bentuk subjektivitas
yang terbentuk darinya, relasi
kekuasaan yang ada di balik
pengetahuan dan praktik sosial
tersebut, serta saling keterkaitan
diantara semua aspek ini.
(foucaulth, 2009: 9)

Ada keterkaitan antara tiga komponen penting dalam apresiasi seni yakni, seniman, karya seni, dan audiance. Apresiasi seni merupakan sikap perilaku apresiator dalam melakukan interaksi komunikasi dengan karya seni sebagai objek pengamatan, penghayatan, penikmatan, merasakan dan menghargai secara utuh untuk mencapai kepuasan apresian.

Sikap perilaku tersebut akan memberikan kontribusi pada pemahaman teori seni yang sangat berarti dalam mempelajari, menyikapi, dan mengkaji teori-teori seni yang ada. Karya seni yang ada tampil dengan segala atribut yang melaket pada masing-masing karya seni yang berupa wujud bentuk struktur seni dan bobot nilai estetis yang merupakan kandungan isi dari karya seni. Maka aplikasi jabaran proses apresiasi atau tanggapan terhadap hasil karya seni dapat dilacak secara ilmiah.

Seniman sebagai agen of change memiliki tujuan dan maksud ketika menciptakan karya, serta berpotensi memiliki fungsi di baliknya. Karya seni yang, unsur fisiknya sangat strategis untuk di analisis secara formal menjadi bagian dari produksi wacana dan sumber produksi pengetahuan untuk dikaji. Pengetahuan yang didapat dari seniman adalah konsep dari penciptaan karya seni, dapat berupa, proses, dan hasil karya seni. Karya seni sebagai objek tanggapan atau apresiasi seni selain sajian tampilan wujud bentuk struktur seni secara visual (unsur atau elemen seni rupa), ada sajian isi, ide dan konsep yang terkandung di dalamnya (pesan, gagasan, propaganda, nilai estetis, bobot) yang diamati, dirasakan, dihayati, dihargai tampilan keberadaanya.

Audince berperan penting dalam memproduksi makna, lewat apresiasi. Audiance dapat berasal dari berbagai kalangan masyarakat, yang terbagi menjadi beberapa segmen dan berasal dari 
berbagai kalangan masyarakat, turut berkontribusi dalam memproduksi makna. Produksi pengetahuan dilakukan dengan adanya interaksi dengan karya seni, dari hasil pengamatan yang diterima indera mata,telinga, pembau, peraba, dan melalui intelegensi, jiwa, hati, rasa seni yang estetis, kemudian diolah, diendapkan, dan dihayati akan menghasilkan berbagaiasumsi dan interpretasi. Hasil pengolahan akan berbentuk dan menghasilkan berbagai pendapat berupa interpretasi, persepsi, asumsi, sense, estetis, intuisi, dan imajinasi kepada masing-masing apresiator.

Apresiator yang paling memiliki kuasa atas produksi wacana dalam seni rupa adalah kritikus seni. Kritikus seni memproduksi wacana yang nantinya menjadi pengetahuan lewat teks ( catalog, buku, diskusi, analisis karya, pencatatan hasil kerja studio, data-data, hasil eksperimen karya, image, audio/rekaman, $\mathrm{dsb}$ ). Dalam menuliskan sesuatu kritikus memiliki struktur diskursif yang menyertainya dalam berfikir. Struktur diskursif tersebut adalah bangunan besar, dan secara sistematis batas-batas itu berbentuk sebuah episteme, perangkata dari struktur diskursif sebagai suatu keseluruhan melalui mana kebudayaan berfikir. Melalui episteme itu, kita mengerti dan memahami suatu objek dengan pernyataan dari pandangan terentu, dan tidak yang lain. Sehigga kemudian kita bisa mengatakan sebagai, menurut pandangan jim supangkat, warno wisetrotomo karya seni yang baik adalah......

Hasil interpretasi dapat memunculkan banyak wacana tergantung pada perspektif yang paling dipercaya dan dipandang benar. Macdonell menuliskan, wacana itu merupakan suatu arena di mana khalayak berfikir dengan jalan tertentu, bukan yang lain. Begitu juga dalam pemaknaan karya seni, lewat teks. Kritikus memaknai karya seni lewat teks berdasarkan pandangan tertentu atau bagaimana karya seni di buat dan dibentuk. Makna tidak intrinsik ada dalam karya seni itu sendiri. Seseorang yang melihat karyab seni tidak menemukan begitu saja makan adalam karya yang terkandung, sebab yang dia hadapi adalah pesan dalam' benda seni' form. Makna itu diproduksi lewat proses yang aktif dan dinamis baik dari sisi pembuat ataupun khalayak pembaca. Seniman, karya seni, dan audiance (pengamat) sama-sama memiliki andil dalam memproduksi pemaknaan, dan hubunganya dengan sistem tata nilai yang lebih besar di mana dia hidup dalam masyarakat. Pada titik inilah pengetahuan diproduksi dan bekerja.

\section{KESIMPULAN}

Dalam Penciptaan sebuah karya seni tentunya tidak akan melupakan seniman sebagai pencipta karya seni. Seniman memiliki konsep sebagai dasar mencipta yang disebut sebagai ide/gagasan/konsep. Konsep Karya seni diciptakan oleh seniman melalui beberapa tahapan, sehingga perlu pemahaman terhadap metode penciptaan dan didukung dengan pemahaman terhadap teori seni. Metode dalam ranah penciptaan sangat mungkin untuk dikembangkan, sebab proses penciptaan karya berkaitan dengan Eksplorasi dimana dapat dikembangkan banyak eksperimen di dalamnya. Metode yang baik digunakan dalam penciptaan seni 
adalah praktik berbasis riset (practice based research).

Karya seni yang merupakan hasil rekayasa, pengolahan, dari pengalamanpengalaman empiris seniman dalam hidupnya dan kehidupanya beraktivitas dalam kegiatan sehari-hari akan memberikan pengetahuan, pemahaman, wawasan, pencerahan kepada seniman sendiri, masyarakat dan komunitas, serta masyarakat pada umumnya. Apresiator (pengamat) seni turut berkontribusi dalam memproduksi pengetahuan. Keterkaitan tiga komponen yakni seniman, karya seni, dan audiance/apresiator (pengamat) seni saling terkait dalam menciptakan dan memproduksi wacana dalam tiap konteks kebudayaan.

\section{Kepustakaan}

Eriyanto. 2011. Analisis Wacana Pengantar Analisis Teks Media. Yogyakarta: LkiS.

Foucault, Michel. 2009. Pengetahuan dan Metode Karya-karya Penting Foucault. Yogyakarta: Jalasutra.

Fryling, Christopher. 1993. Research in Art and design. Royal collage of Art Research Papers 1 (1): 1-5.

Gray, Carol. MALINS, JULIAN. 2004. Visualizing Research, A guide to the research process in art and design. Ashgate Publishing Limited.

1998. "Inhuiry through practice: Developing appropriate research strategies in art and design". University of Art \& Design Helsinki.
Kaelan, H. 2012. Metode Penelitian Kualitatif Interdisipliner Bidang Sosial, Budaya, Filsafat, Seni, Agama, dan Humaniora. Yogyakarta: PARADIGMA.

Marianto, Dwi. 2002. Seni Kritik Seni. Yogyakarta: Lembaga Penelitian Institut Seni Yogyakarta.

Sachari, Agus. 2005. Pengantar Metodologi Penelitian Budaya Rupa: Desain, Arsitektur, Seni Rupa, dan Kriya. Jakarta: ERLANGGA.

Sugiharto, Bambang. 2013. Untuk Apa Seni. Bandung: Matahari.

\section{Artikel Jurnal}

Sattar, M. 2012. "Proses Apresiasi dan Kreasi Dalam Tritunggal Seni" dalam URNA Jurnal Seni Rupa, Vol.1, No. 1 (Juni 2012): 1-105. 